\title{
PENGARUH MEDIA SOSIAL FACEBOOK TERHADAP PERKEMBANGAN E-COMMERCE DI INDONESIA
}

\author{
Sarif Hidayat \\ Jurusan Magister Ilmu Komputer \\ Universitas Budi Luhur - Jakarta \\ Email: sarifhid@gmail.com \\ Hari Suryantoro \\ Jurusan Magister Ilmu Komputer \\ Universitas Budi Luhur - Jakarta \\ Email: akoehari@gmail.com \\ Jansen Wiratama \\ Jurusan Magister Ilmu Komputer \\ Universitas Budi Luhur - Jakarta \\ Email: jansenwiratama@gmail.com
}

\begin{abstract}
ABSTRAK
Media sosial memang bukanlah hal yang baru dalam dunia modern sekarang ini, dimulai dari facebook, twitter, Path, Instagram dan masih banyak lagi. Peran media sosial memang dirasa sangat membantu bagi mereka yang ingin mencari teman yang mungkin sudah lama tidak bertemu. Selain fungsi "sosial" media sosial saat ini bertransformasi menjadi sebuah media untuk menciptakan sebuah fenomena baru dalam dunia ekonomi, diantaranya sebagai media promosi hingga transaksi jual beli, hal ini menjadi sebuah kekuatan baru dalam dunia ekonomi dimana kita bisa memangkas biaya pemasaran dengan tidak mengurangi pemasukan bahkan pemasaran bisa lebih efektif. Tujuan penulisan ini adalah untuk mengetahui seberapa besar fungsi media sosial khususnya facebook dalam perkembangan e-commerce di Indonesia. Metode yang digunakan dalam penelitian ini adalah dengan menggunakan studi literatur atau kajian yang berkaitan dengan topik sejenis dan hasil dari penelitian ini diharapkan dapat membuktikan bahwa facebook dapat berpengaruh terhadap perkembangan e-commerce di Indonesia.
\end{abstract}

Kata kunci: media sosial, facebook, e-commerce.

\section{ABSTRACT}

Nowadays Social media is not a new think in modern world, starting from facebook, twitter, path, Instagram and many more. The role of social media is considered very helpful for those who wish for a friend who may not have long to meet. In addition to the "social" social media is now transformed into a media to create a new phenomenon in the world economy, such as media campaigns to buying and selling, it is becoming a new force in the world economy in which we can cut marketing costs by not reducing income even marketing can be more effective. The objective is to find out how big the social media, especially facebook in the development of e-commerce in Indonesia. This research used method study of literature related with the same topic and the results of this study are expected to prove that facebook can affect the development of e-commerce in Indonesia.

Keywords: social media, facebook, e-commerce.

\section{PENDAHULUAN}

Maraknya media sosial menjadi trend tersendiri dalam kehidupan masyarakat khususnya di Indonesia, seakan-akan hal tersebut menjadi kegiatan rutin yang harus dilakukan setiap hari. Penggunaan media sosial yang dilakukan oleh beberapa lembaga survei ternyata cukup mengesankan dari data yang di peroleh dari APJII (Asosiasi Penyelenggara Jasa Internet Indonesia) pada tahun 2016 di peroleh bahwa penggunaan internet di Indonesia berdasarkan konten yang paling sering dikunjungi 97,4\% adalah media sosial seperti terlihat pada gambar di bawah ini : 


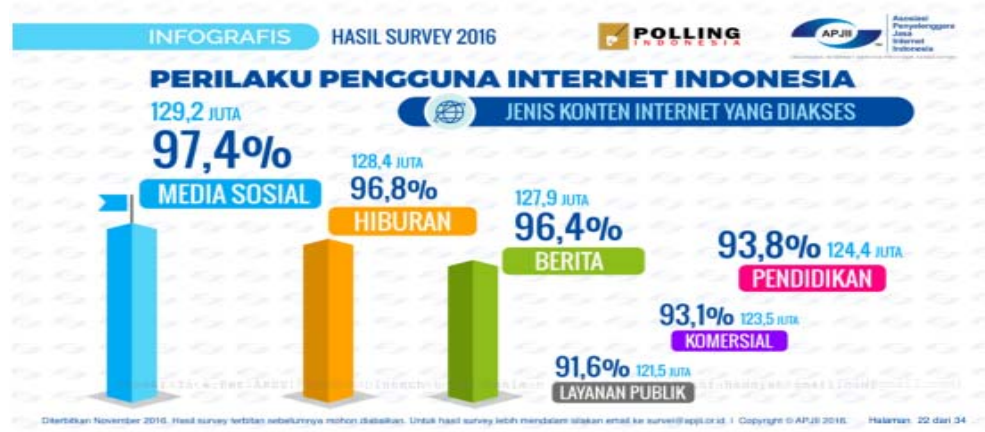

Gambar 1. Hasil Survei APJII 2016 Berdasarkan Konten Yang Dikunjungi [1]

Dari data di atas menggambarkan bagaimana pengguna internet di Indonesia khususnya yang mengakses media sosial menempati urutan teratas. Kemudahan dalam bersosialisasi dan saling bertukar informasi adalah salah satu manfaat yang dirasakan oleh pengguna ditambah lagi aplikasi ini bersifat free atau gratis dan bisa dipasang di perangkat mobile. Tingginya tingkat penggunaan media sosial diterjemahkan sebagai peluang untuk berbagai aktivitas seperti beriklan. Bermunculannya iklan di media sosial dengan cara dan tampilan yang dikemas sedemikian rupa membuat konsumen merasa tertarik untuk membeli, serta kemudahan untuk mendapatkan informasi tentang produk yang mereka cari karena konsumen bisa langsung berinteraksi dengan penjual secara langsung sehingga hubungan trust antara kedua belah pihak dapat terjalin. Media sosial merupakan fenomena baru yang telah mengubah cara lingkungan bisnis berjalan. Melalui media sosial kegiatan bisnis mendapatkan akses yang tidak terbatas hal ini bisa membantu perusahaan atau individu dapat meningkatkan kontak mereka dengan pelanggan dan pemasok.

Ada banyak jenis media sosial yang sekarang banyak digunakan salah satu nya adalah facebook, sebuah studi oleh TNS (Taylor Nelson Sofres) untuk facebook kepada 1000 orang Indonesia yang gemar belanja online mengatakan, media sosial memiliki peran besar terhadap pertumbuhan e-commerce di Indonesia. Mulai dari mencari riset produk, hingga melakukan pembayaran. Sebagai gambaran sederhana, 86 dari 100 persen survei setiap harinya selalu mengakses situs facebook. Selama 2 jam dihabiskan untuk berkomunikasi, dan selama 65 menit setiap harinya dihabiskan untuk berbelanja online. Pada intinya, orang Indonesia gemar mengakses facebook karena berbagai fitur yang ditawarkan. Di saat yang bersamaan pula, facebook juga menawarkan fitur untuk menjangkau pasar lebih mudah khusus bagi para pelaku bisnis.

Berdasarkan uraian di atas, ada beberapa masalah yang akan diteliti yaitu :

1) Apakah facebook berpengaruh terhadap perkembangan e-commerce di Indonesia?

2) Bagaimana tingkat kepercayaan konsumen terhadap transaksi e-commerce melalui facebook?

3) Mengapa facebook banyak digunakan sebagai media transaksi e-commerce?

Pada penelitian sebelum nya yang dilakukan oleh Heru nugroho dan kastaman menggunakan metode literature dimana dilakukan pengolahan data penjualan untuk membandingkan dua buah bisnis sebelum dan sesudah menggunakan media sosial facebook [2].

\section{METODOLOGI}

Metode yang digunakan dalam penelitian ini adalah melakukan kajian atau studi literature berkaitan dengan topik penelitian sejenis sebagai pendukung dari penelitian ini serta sejauh mana penelitianpenelitian sebelumnya dengan topik yang berkaitan sudah berkembang sehingga penelitian ini menghasilkan sebuah pengetahuan baru.

\section{LANDASAN TEORI}

\subsection{Media Sosial Facebook}

Salah satu bentuk komunitas untuk komunikasi online yang ampuh saat ini adalah media sosial. Media sosial adalah sebuah pengembangan bentuk kreasi informasi dan interaksi yang mempunyai potensi signifikan untuk pemasaran [3]. 
Facebook diluncurkan pertama kali pada Februari 2004 oleh Mark Zuckerberg dan saat ini facebook adalah salah satu media sosial yang paling banyak digunakan oleh masyarakat Indonesia.

Dari beberapa media sosial yang ada seperti twitter, instagram, youtube, google plus, linked in, facebook menjadi salah satu media sosial yang paling popular saat ini karena penggunanya setiap hari bertambah dari waktu ke waktu. Selain itu juga menurut survey yang dilakukan oleh APJII pada tahun 2016 tercatat bahwa 54\% pengguna internet di Indonesia mengakses facebook.

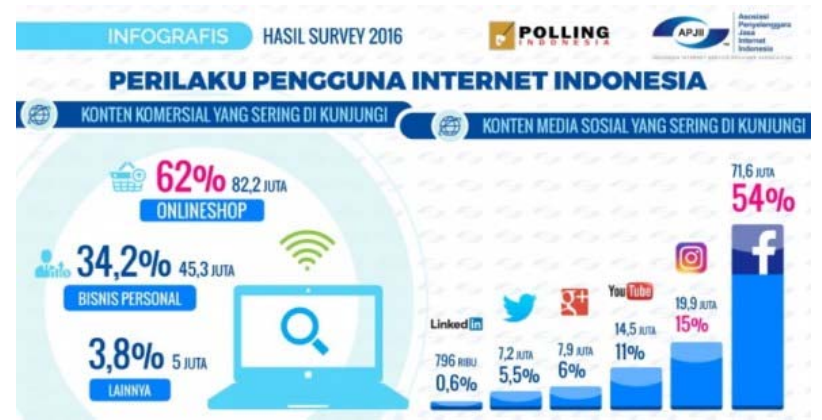

\section{Gambar 2. Hasil Survey APJII 2016 Tentang Konten Media Sosoal Yang Sering Di Kunjungi Di Indonesia [1]}

Berdasarkan hasil yang diperoleh survey di atas didapat bahwa $62 \%$ perilaku pengguna internet di Indonesia adalah onlineshop dan 54\% konten media sosial facebook. Sementara itu penggunaan facebook berdasarkan negara didapat dari situs www.statista.com pada bulan April 2017 bahwa Indonesia menempati posisi ke empat setelah Brazil yang ditunjukan dalam gambar di bawah ini

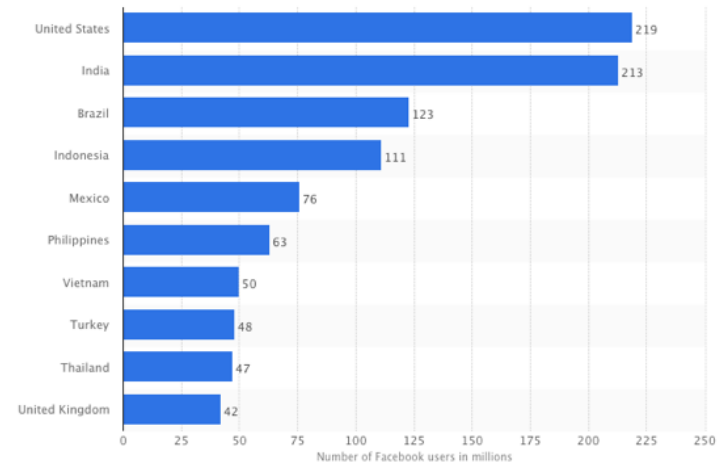

Gambar 3. Penggunaan Facebook Setiap Negara [4]

\subsection{E-Commerce}

Menurut definisi nya e-commerce adalah proses pembelian, penjualan dan pertukaran produk, service dan informasi yang dilakukan melalui jaringan komputer yaitu internet. E-commerce atau kependekan dari electronic commerce (perdagangan secara elektronik), merupakan transaksi bisnis yang terjadi dalam jaringan elektronik, seperti internet. Siapapun yang dapat mengakses komputer, memiliki sambungan ke internet, dan memiliki cara untuk membayar barang-barang atau jasa yang mereka beli, dapat berpartisipasi dalam e-commerce.

E-commerce memiliki beberapa komponen standar yang di miliki dan tidak dimiliki transaksi bisnis yang dilakukan secara offline[5], yaitu :

1) Produk: banyak jenis produk yang bisa dijual melalui internet seperti komputer, buku, musik, pakaian, mainan, dan lain-lain.

2) Tempat menjual produk (a place to sell): tempat menjual adalah internet yang berarti harus memiliki domain dan hosting.

3) Cara menerima pesanan: email, telepon, sms dan lain-lain

4) Cara pembayaran: Cash, check, bankdraft, kartu kredit, internet payment (misalnya paypal)

5) Metode pengiriman : pengiriman bisa dilakukan melalui paket, salesman, atau diunduh jika produk yang dijual memungkinkan untuk itu (misalnya software). 
6) Customet service : email, formulir on-line, FAQ, telepon, chatting, dan lain-lain.

Ada banyak cara untuk mengklasifikasikan transaksi e-commerce. Salah satunya dengan melihat sifat peserta yang terlibat dalam transaksi e-commerce. Berdasarkan sifat penggunanya, e-commerce dibagi menjadi 3 jenis[6]:

1) E-commerce bisnis ke konsumen (B2C) melibatkan penjualan produk dan layanan secara eceran kepada pembeli perorangan.

2) E-commerce bisnis ke bisnis (B2B) melibatkan penjualan produk dan layanan antar perusahaan.

3) E-commerce konsumen ke konsumen (C2C) melibatkan konsumen yang menjual secara langsung ke konsumen.

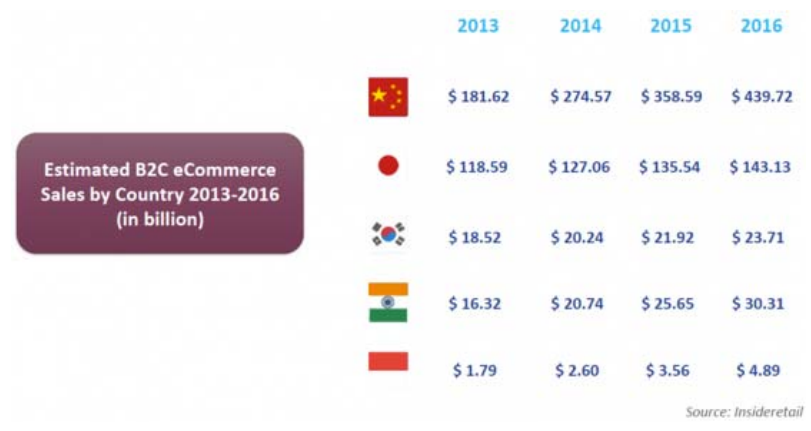

Gambar 4. Estimasi Penjualan E-Commerce [7]

Data diatas menunjukan bahwa walaupun jumlah penjualan di Indonesia masih rendah dibanding negara lainya, namun melihat perkembangan Indonesia yang cukup pesat, tidak menutup kemungkinan Indonesia akan akan menyaingi negasa Asia lain yang sudah dulu menghasilkan penjualan e-commerce di atas Indonesia.

\section{PEMBAHASAN}

Seperti yang sudah dipaparkan di atas bahwa penggunaan media sosial khususnya facebook sangat diminati di Indonesia, hal ini yang dimanfaatkan oleh para pelaku bisnis e-commerce untuk memasarkan produk mereka dengan memanfaatkan facebook sebagai media untuk promosi.

Untuk menganalisa bertumbuhnya perkembangan e-commerce di Indonesia, berikut merupakan trend perkembangan e-commerce di Indonesia [8] : Perkembangan e-commerce di Indonesia pada tahun 2000 hingga tahun 2010 belum efektif, dikarenakan beberapa hal di antaranya :

1) Perkembangan e-commerce di Indonesia pada tahun 2000 hingga tahun 2010 belum efektif, dikarenakan beberapa hal di antaranya penyedia internet di Indonesia yang terbatas hingga kejahatan cyber seperti hacker, carding, cracker dan cyberfraud. Bahkan pada tahun 2004 calon pembeli di Indonesia dimasukan daftar hitam oleh situs e-bay.com.

2) Tahun 2010 berkembang konsep Daily Deal Service (DDS), yaitu menawarkan diskon produk atau jasa dalam periode ternetu melalui jejaring sosial dan email.

3) Tahun 2011 mulai bermunculan market place secara unik menjadikan media sosial, forum sebagai sarana baru untuk berbisnis dan mengedukasi masyarakat tentang e-commerce.

4) Tahun 2012 trend e-commerce meninggalkan konsep DDS dan beralih ke market place. Meningkatnya pengunjung masyarakat ke situs e-commerce mulai dari window shopping, membeli pakaian, buku, menjadikan media sosial menjadi sarana baru bisnis e-commerce.

5) Trend 2013 mengubah cara membayar menjadi penawaran secara tunai dan COD (Cash On Delivery), toko online mulai terintegrasi dengan smartphone.

6) Trend tahun 2014 berkembangnya smartphone, free shipping, faster shipping, content marketing, guided discovery dan based on costumer want.

7) Tahun 2015 trend e-commerce di Indonesia diperidiksi juga akan mengalami peningkatan seiring dengan berkembangnya industri smartphone di tanah air [9]. Sedangkan menurut riset yang dilakukan oleh firma konsultan bisnis dan manajemen AT Kearny, nilai penjualan global ecommerce tahun 2015 hampir mencapai 1 triliun dolar Amerika atau tumbuh sebesar 18\% dibandingkan tahun 2014 [10].

8) Data Survey yang dilakukan oleh MARS tahun 2016 bahwa bisa dikatakan semua orang yang mengakses internet setidaknya mempunyai 1 akun di media sosial. Namun media sosial mana 
yang banyak digunakan? Ternyata media sosial facebook yang sering banyak digunakan dengan presentase $93.5 \%$.

Dengan pertumbuhan pengguna aktif facebook setiap harinya, maka facebook menjadi sebuah tempat yang sangat potensial untuk melakukan penjualan, iklan dan melakukan aktifitas e-business [11]. Salah satu aktifitas bisnis yang dimaksud adalah e-commerce dalam facebook atau dikenal juga sebagai facebook commerce (F-Commerce).

$F$-commerce adalah kemampuan untuk menjalankan transaksi pada facebook tanpa meninggalkan jarngan dan integrasi facebook pada bentuk tradisional e-commerce berbasis web [12]. Fitur-fitur yang dimiliki oleh $f$-commerce adalah [12]:

1) Media pemasaran gratis pada facebook.

a) Facebook Pages (halaman facebook).

b) Memungkinkan pemasar untuk membangun profil, melibatkan pengunjung, dan berbagi pesan.

c) Facebook Group, digunakan untuk mempercepat hubungan pemasar dengan penggemar dan pengguna.

d) Facebook Questions, memungkinkan pemilik halaman menjawab pertanyaan-pertanyaan yang berhubungan dengan bisnis mereka, dengan administrator yang dapat mengirimkan pertanyaan langsung pada halaman mereka.

e) Facebook Connect merupakan suatu cara untuk mendapatkan pengunjung untuk berbagi konten pemasar.

2) Iklan sosial facebook

Agar pemasar dapat menembus pasar yang lebih besar, facebook menawarkan sosial aids (Iklan sosial) yang memungkinkan pemasar dapat terhubung dengan labih dari 500 juta konsumen potensial.

3) Sponsored Stories pada facebook

Sebuah alat dari facebook yang memungkinkan pengiklan untuk membayar "sponsor" orang yang membuat komentar tentang bisnis, tempat atau produk pada facebook.

Facebook merupakan pelopor dalam menciptakan peluang-peluang sosial ekonomi yang belum direalisasikan sampai saat ini, dengan pertumbuhan yang luar biasa dan teknologi yang unik, facebook mampu memberikan layanan yang terintegrasi ke dalam kehidupan sehari-hari bagi banyak pengguna di seluruh jaringan global. Pertumbuhan tersebut menciptakan inisiatif e-commerce baru dan model-model bisnis yang inofatif didasarkan pada kekuatan persahabatan dan dari mulut ke mulut[13].

\section{KESIMPULAN}

Berdasarkan paparan di atas maka dapat disimpulkan bahwa facebook berperan penting dalam perkembangan e-commerce di Indonesia, dengan beberapa fitur yang diberikan oleh facebook serta dengan didukung oleh data dari berbagai lembaga survei menunjukkan bahwa facebook bukan hanya sekedar media untuk menjalin pertemanan tetapi juga dapat dijadikan sebagai media untuk membantu meningkatkan perekonomian, karena sifatnya yang mudah terhubung membuat facebook dijadikan sebagai media yang ampuh untuk promosi produk atau jasa.

\section{DAFTAR PUSTAKA}

[1] APJII, "Penetrasi \& Perilaku Pengguna Internet Indonesia 2016," 2016.

[2] H. Nugroho and Kastaman, "Pengaruh Media Sosial Facebook Dalam Peningkatan Penjualan Bisnis Online,” Pros. Semin. Nas. Apl. sains Teknol., 2014.

[3] B. J. Jansen, K. Sobel, and G. Cook, "Classifying ecommerce information sharing behaviour by youths on social networking sites," J. Inf. Sci., vol. 37, no. 2, pp. 120-136, 2011.

[4] Statista, "Leading countries based on number of Facebook users as of July 2017 (in millions)," 2017.

[5] T. Hidayat, Panduan Membuat Toko Online dengan OSCommerce. MediaKita, 2008.

[6] K. C. Laudon and J. P. Laudon, Sistem Informasi Manajemen, 10th ed. jakarta: Salemba Empat, 2008.

[7] Majalah Marketing, "Estimated B2C Ecommerce Sales By Country 2013-2016," 08/XIV/Agustus/2014, 2014.

[8] R. Kurnia and B. Priambodo, "Pengaruh Sosial Media Terhadap Bisnis E-Commerce Di Indonesia," 
J. Ilm. e-commerce Sist. Inf., 2014.

[9] Apkomindo, "2015, Pasar E-Commerce Berpotensi Meningkat," 2015. [Online]. Available: https://www.apkomindo.id/index.php/logo/item/96-2015-pasar-e-commerce-berpotensi-meningkat. [Accessed: 01-Jan-2017].

[10] Presidenri.go.id, "Membuka dan Mengembangkan Potensi E-Commerce di Indonesia," 2016. [Online]. Available: http://presidenri.go.id/berita-aktual/membuka-dan-mengembangkan-potensi-ecommerce-di-indonesia.html. [Accessed: 01-Jan-2017].

[11] C. Treadaway and M. Smith, "Facebook Marketing," Media, vol. 1, no. 2, p. 312, 2010.

[12] Linda and S. Lai, "Facebook Lessons for E-Business Startups," Int. J. Soc. Behav. Educ. Econ. Bus. Ind. Eng., vol. 5, 2011.

[13] Linda and S. Lai, "Social Commerce - E-Commerce in Social Media Context," Int. J. Soc. Behav. Educ. Econ. Bus. Ind. Eng., vol. 4, 2010. 